D0I:10.17951/we.2019.5.1.185-201 $\quad$ Wschód Europy • Восток Европы • East of Europe vol 5, 1 / 2019

Ireneusz Topolski

ORCID: https://orcid.org/0000-0001-7152-8329

Uniwersytet Marii Curie-Skłodowskiej w Lublinie, Wydział Politologii i Dziennikarstwa

\title{
Manewry wojskowe jako forma demonstracji siły militarnej Federacji Rosyjskiej w Europie
}

M anewry wojskowe stanowią jedną z form demonstracji siły militarnej, tj. instrumentu militarnego polityki zagranicznej państwa. Mogą się one wiązać z przeprowadzaniem różnych ćwiczeń, także w strefie przygranicznej oraz w pobliżu morza terytorialnego. Towarzyszyć im może równość gotowość jednostek czy też poszczególnych oddziałów wojskowych do podjęcia działań, w tym o charakterze bojowym. Ważną kwestię stanowi podnoszenie stanu gotowości bojowej wojsk, szczególnie przeprowadzone w sposób niezapowiedziany i nagły ${ }^{1}$.

Johan Norberg wskazał na znaczenie ćwiczeń wojskowych w polityce zagranicznej państwa. Po pierwsze, prowadzone manewry wojskowe w okresie pokoju mają „pokazywać” potencjalne możliwości bojowe w czasie wojny. Jednocześnie realizacja tylko ćwiczeń na poziomie taktycznym może powodować problemy w przypadku podjęcia operacji o charakterze strategicznym. Po drugie, manewry stanowią wyznacznik ambicji państwa wobec sił zbrojnych, tj. jednego ze sposobów ich wykorzystania. W takim przypadku, jeżeli w danym państwie są prowadzone manewry wojskowe o charakterze strategicznym, oznacza to, iż założono możliwość realizacji tego rodzaju operacji. Po trzecie, realizacja manewrów wojskowych w bardzo dużym stopniu wpływa na poziom mobilności i gotowości jednostek bojowych ${ }^{2}$.

Zakres chronologiczny niniejszego artykułu obejmuje okres po wojnie Federacji Rosyjskiej z Gruzją w sierpniu 2008 r., do roku 2018. Pierwsza kwestia wpłynęła na relacje z Organizacją Traktatu Północnoatlantyckiego (NATO), a szczególnie przełożyła się na konieczność reformy sił zbrojnych. Celem artykułu jest analiza wpływu manewrów woj-

1 I. Topolski, Instrument militarny polityki zagranicznej państwa, „TEKA Komisji Politologii i Stosunków Międzynarodowych" 2016, t. 11, z. 3, s. 154; R. Łoś, Teoria stosunków międzynarodowych. Wybrane zagadnienia, Łódź 2001, s. 40-41; H.J. Morgenthau, przejrzał i uzupełnił K.W. Thompson, Polityka między narodami. Walka o potęgę i pokój. Wydanie skrócone, Warszawa 2010, s. 104-106.

2 J. Norberg, Training for War - What Military Exercises 2009-2017. Say About the Fighting Power of Russia's Armed Forces, Report no FOI-R--4627-SE, 2018, October, p. 13-14. 
skowych jako formy demonstracji siły militarnej Federacji na poziom bezpieczeństwa Obszaru Transatlantyckiego. Często są one połączone z przemieszczaniem i koncentracją jednostek również przy granicy z innymi państwami. Towarzyszy temu także ogłaszanie niezapowiedzianych inspekcji oraz podnoszenie stanu gotowości bojowej wojsk. W pewnych sytuacjach występują również przypadki powoływania rezerwistów. W pracy przyjęto dwie hipotezy badawcze.

Po pierwsze, strategiczne manewry wojskowe Federacji Rosyjskiej, mimo iż oficjalnie według rosyjskich decydentów mają założenie obronne, jednak w praktyce ze względu na ich charakter i zakres są postrzegane przez państwa Europy Środkowo-Wschodniej jako ofensywne.

Po drugie, manewry wojskowe połączone z niezapowiedzianymi i nagłymi inspekcjami, którym towarzyszy także przegrupowanie jednostek, znacząco podniosły możliwości bojowe Sił Zbrojnych Federacji Rosyjskiej.

$\mathrm{W}$ tej części pracy zostaną scharakteryzowane uwarunkowania militarne wpływu manewrów wojskowych prowadzonych przez Federację Rosyjską przede wszystkim na poziom bezpieczeństwa Obszaru Transatlantyckiego. Ze względu na złożoność tematu scharakteryzowano najważniejsze problemy, poczynając od skutków wojny z Gruzją w sierpniu 2008 roku dla Rosji. W dalszej części analizie poddano specyfikę manewrów wojskowych prowadzonych przez Federację.

\section{Uwarunkowania militarne}

Wojna Federacji Rosyjskiej z Gruzją w sierpniu 2008 r. obnażyła wszystkie słabe punkty armii. Mimo iż kampania przeciwko znacząco słabszemu sąsiadowi zakończyła się zwycięstwem, to jednak pojawiło się wiele kontrowersji. Stopniowo zaczęto wskazywać na poniesione straty, a także popełnione $\mathrm{w}$ trakcie działań zbrojnych błędy oraz braki w wyposażeniu. Sytuacja ta wymusiła - mimo sprzeciwu ze strony wyższych kadr oficerskich - przyśpieszenie odbudowy armii, co przede wszystkim wiązało się $\mathrm{z}$ rozpoczęciem procesu jej reformowania. W siłach zbrojnych zaczęto wprowadzać w życie wnioski wyciągnięte z tegoż konfliktu zbrojnego. Podstawowy cel reformy zakładał modernizację sił zbrojnych, który miał doprowadzić do rozbudowy potencjału militarnego oraz „przywrócenia” i zwiększenia możliwości prowadzenia działań przez siły konwencjonalne³. W roku 2009 Ministerstwo Obrony Federacji rozpoczęło dużą

3 Russia Military Power 2017: Building a Military to Support Great Power Aspirations, Defense Intelligence Agency Report, p. 12-13, https://publicintelligence.net/dia-russia-military-power-2017/, inf. 11.02.2018; E. Rumer, Russia and the Security of Europe, "Carnegie Endowment for International Peace", 30 June 2016, p. 11, http://carnegieendowment.org/2016/06/30/russia-and-security-of-europe-pub-63990, inf. 11.01.2018; T. Braun, The Russian Military in 2020: Russia's Way Back to Power Projection? Implications for NATO, „Connections: The Quarterly Journal” 2012, vol. 11, no. 2, p. 67-73; R.C. Nation, Russia and the Caucasus, „Connections: The Quarterly Journal” 2015, vol. 14, no. 2, p. 6; J. Lough, Handling Russia Should Not Be So Difficult for the West, Chatham House, The Royal Institute of International Affairs, 21 February 2017, https://www.chathamhouse.org/expert/comment/ handling-russia-should-not-be-so-difficult-west, inf. 28.02.2018; G. Friedman, J.L. Shapiro, Forecasting 
reorganizację Sił Zbrojnych. Armia Rosji przechodzi transformację, co w konsekwencji prowadzi do znaczącej zmiany, która bezpośrednio przekłada się na istotny wzrost jej zdolności wojskowych, w tym realizacji misji o charakterze bojowym. Ponadto realizowany projekt zakłada zwiększenie gotowości bojowej jednostek wojskowych, bez konieczności ich mobilizacji. Należy w tym przypadku wskazać aneksję Półwyspu Krymskiego, wsparcie dla separatystów w Donbasie od wiosny 2014 r., jak również rozpoczęcie we wrześniu $2015 \mathrm{r}$. operacji ekspedycyjnej w Syrii ${ }^{4}$.

Wzrost zdolności oraz inicjatywy Federacji do podejmowania szerszych działań wojskowych bez wyraźnego ostrzeżenia jest problemem dość złożonym. Z jednej strony stwarza istotne zagrożenie dla utrzymania bezpieczeństwa i stabilności na Obszarze Transatlantyckim ${ }^{5}$. Sytuacja ta bezpośrednio przekłada się na relacje Rosji z Zachodem, które określono jako „najgorsze” od połowy lat 80. XX w., lub wręcz jako „nowa zimna wojna"6. Aneksja Krymu przez Federację w marcu 2014 r. stanowiła ostatni etap długoletniego procesu odrzucania euroatlantyckiego systemu bezpieczeństwa, który powstał po zakończeniu zimnej wojny. Wydarzenie to stało się także wyraźnym sygnałem dla Sojuszu Północnoatlantyckiego, iż nie należy podważać wpływów Rosji. Natomiast konflikt zbrojny we wschodniej części Ukrainy doprowadził do nowego okresu rywalizacji pomiędzy Federacją i Zachodem. Zdaniem Jamesa Sherra, porządek prawny i system bezpieczeństwa w Europie po zimnej wojnie się załamał? .

Russia in 2017, „Mauldin Economics” 2016, 14 December, http://www.mauldineconomics.com/ this-week-in-geopolitics/forecasting-russia-in-2017, inf. 01.03.2018.

4 K. Giles, Assessing Russia's Reorganized and Rearmed Military, Carnegie Endowment for International Peace, Task Force White Paper, 3 May 2017, p. 1, http://carnegieendowment.org/2017/05/03/assessing-russia-s-reorganized-and-rearmed-military-pub-69853, inf. 10.01.2018; Russia Military Power 2017..., p. 13, 43; T. Braun, op. cit., p. 70-78; M. Galeotti, 'Hybrid War' and 'Little Green Men': How It Works, and How It Doesn't, [in:] Ukraine and Russia. People, Politics, Propaganda and Perspectives, eds A. PikulickaWilczewska, R. Sakwa, Bristol 2016, p. 150-155, http://www.e-ir.info/wp-content/uploads/2015/03/ Ukraine-and-Russia-E-IR.pdf, inf. 21.02.2018; I.M. Ciolan, The Role Of The "New Cold War" Concept In Constructing Russia'S Great Power Narrative, „CES Working Papers, Centre for European Studies, Alexandru Ioan Cuza University, vol. 8, 2016, issue 4, p. 625-626, http://www.ceswp.uaic.ro/articles/ CESWP2016_VIII4_CIO.pdf, inf. 21.02.2018; K. Giles, Russia's 'New' Tools for Confronting the West Continuity and Innovation in Moscow's Exercise of Power, „Research Paper” 2016, March, p. 13-14, https://www.chathamhouse.org/sites/files/chathamhouse/publications/2016-03-russia-new-tools-giles. pdf, inf. 28.02.2018; J. Norberg, op. cit., p. 14; S. Koziej, Strategiczne wnioski z manewrów Zapad 2017: budowa przez Rosje „,bezpiecznika” w neozimnowojennej grze z Zachodem, http://koziej.pl/wp-content/ uploads/2017/09/Wnioski-z-ZAPAD-Pulaski_Policy_Papers_Nr_19_17.pdf, inf. 25.04.2019.

5 D. Matsaberidze, Russia vs. EU/US through Georgia and Ukraine, „Connections: The Quarterly Journal" 2015, vol. 14, no. 2, p. 80.

6 Competing Western and Russian narratives on the European order: Is there common ground?, Conference Report, eds T. Frear, L. Kulesa „European Leadership Network” 2016, April, p. 2, https:// www.europeanleadershipnetwork.org/wp-content/uploads/2017/10/ELN-Competing-NarrativesReport.pdf, inf. 21.02.2018; I.M. Ciolan, op. cit., p. 625-642.

7 E. Rumer, op. cit., p. 1-3; Ch. Le Mière, Maritime Diplomacy in the 21st Century. Drivers and Challenges, London, New York 2014, p. 77; D. Matsaberidze, op. cit., p. 84-85; J. Sherr, A War of Narratives and 
David Tier wskazał, iż Stany Zjednoczone Ameryki poza wprowadzeniem sankcji, w celu wyrażenia zdecydowanego protestu przeciw agresji Rosji na Ukrainę, rozmieściły niewielkie jednostki wojskowe w regionie. Mimo iż działania te mają charakter symboliczny, stanowią jednak formę demonstracji siły militarnej przez USA ${ }^{8}$. Szczególnie było to istotne w przypadku dyslokacji wojsk na Litwie, Łotwie i w Estonii'.

Według Eugene’a Rumera, przewaga pod względem potencjału sił konwencjonalnych państw NATO przekłada się na ich większe zdolności bojowe i powoduje, iż Siły Zbrojne Federacji nie są przygotowane do prowadzenia wojny konwencjonalnej o dużej skali. $\mathrm{W}$ konsekwencji w takiej sytuacji istotną rolę odgrywa taktyczna broń jądrowa Rosji ${ }^{10}$. Zbliżone stanowisko zaprezentował Michael Kofman (Instytut Kennana), który wskazał, że demonstrowanie wysokiego poziomu możliwości działania sił konwencjonalnych nie oznacza, że są one przeznaczone do prawdziwej walki. Podstawowym ich zadaniem jest przede wszystkim oddziaływanie na Stany Zjednoczony Ameryki ${ }^{11}$.

Należy także zaznaczyć, iż stały rozwój i transformacja Sił Zbrojnych Rosji stopniowo prowadzi do ograniczania istniejącej przewagi Zachodu pod względem potencjału militarnego, szczególnie w ujęciu jakościowym. Sytuacja taka powoduje coraz bardziej aktywne działania Federacji o charakterze wojskowym w regionie ${ }^{12}$. Kwestie te są szczególnie widoczne i jednocześnie przekładają się na formy demonstracji siły militarnej, w tym charakter i zakres manewrów realizowanych przez Rosję wobec państw Zachodu.

\section{Specyfika manewrów wojskowych}

Od roku 2009 Rosja rozpoczęła realizację corocznych strategicznych ćwiczeń wojskowych $^{13}$. W okresie 2011-2013 Siły Zbrojne Federacji regularnie prowadziły strategiczne manewry wojskowe, które obejmowały znaczne obszary państwa. W roku 2013 uległy

Arms, Chatham House Report: The Russian Challenge, 2015, June, p. 23, https://www.chathamhouse. org/sites/files/chathamhouse/field/field_document/20150605RussianChallengeGilesHansonLyneNixeySherrWoodUpdate.pdf, inf. 01.03.2018; A. Monaghan, A 'New Cold War'? Abusing History, Misunderstanding Russia, „Research Paper” 2015, May, p. 1, http://caa-network.org/cassions/wp-content/ uploads/2015/05/20150522ColdWarRussiaMonaghan.pdf, inf. 28.02.2018.

8 D. Tier, Regional Alliances: A Political, Military, and Economic Strategy to Confront Hostile Regional Powers, „Connections: The Quarterly Journal” 2014, vol. 13, no. 4, p. 25-26.

9 Z. Studzińska, How Russia, Step by Step, Wants to Regain an Imperial Role in the Global and European Security System, „Connections: The Quarterly Journal” 2014, vol. 14, no. 4, p. 36.

10 E. Rumer, op. cit., p. 17-18.

11 K. Giles, Assessing Russia's Reorganized..., p. 11.

12 A. Wood, Russian and Western Expectations, Chatham House Report: The Russian Challenge, 2015, June, p. 54, https://www.chathamhouse.org/sites/files/chathamhouse/field/field_document/20150605Russian ChallengeGilesHansonLyneNixeySherrWoodUpdate.pdf, inf. 01.03.2018.

13 W latach 2009-2010 miały one charakter operacyjno-strategiczny, a od 2011 prowadzono je na poziomie strategicznym. Natomiast Dave Johnson wskazał, iż coroczne ćwiczenia strategiczne zapoczątkowały w roku 2008 manewry Kaukaz-2008 (Kawkaz-2008). Zob.: D. Johnson, WOSTOK 2018: dziesięć lat rosyjskich ćwiczeń strategicznych i doskonalenia sztuki wojennej, „Przegląd NATO” 20.12.2018, https://www.nato.int/docu/review/2018/Also-in-2018/vostok-2018-ten-years-of-russian-strategic-e xercises-and-warfare-preparation-military-exercices/PL/index.htm\#f5, inf. 23.05.2019. 
one przewartościowaniu. Po pierwsze, nastąpił znaczący wzrost ilościowy pod względem zaangażowanego w nich personelu i techniki wojskowej. Natomiast druga cecha wiązała się z udziałem w nich coraz większej liczby wojsk z innych ministerstw $i$ agencji, tj. struktur siłowych w Rosji. Po trzecie, dodatkowo wymiar tych działań uległ wzmocnieniu, gdy Federacja Rosyjska w roku 2013 rozpoczęła - czy też wznowiła z okresu ZSRR - nagłe inspekcje o dużej skali, które towarzyszyły manewrom wojskowym. Ich celem stały się niezapowiedziane kontrole gotowości bojowej wojsk. W konsekwencji w późniejszym okresie były one kontynuowane. Stanowiły także rolę „przykrywki” do prowadzenia kolejnych operacji albo form wywierania nacisku na Ukrainę. Ponadto w celu zapewnienia bezpieczeństwa w związku z trwającymi w dniach 7-23 lutego 2014 r. Zimowymi Igrzyskami Olimpijskimi w Soczi podniesiono stan gotowości bojowej jednostek w Południowym OW ${ }^{14}$.

Do specyficznych cech, które charakteryzują manewry wojskowe prowadzone przez Rosję, zalicza się ${ }^{15}$ :

1) ogromna skala zaangażowanego potencjału militarnego, tj. poziom wykorzystanych wojsk i środków walki oraz sprzętu technicznego, który jest bardzo duży. W czasie ich realizacji zakładano lub symulowano możliwość prowadzenia wojen międzypaństwowych z ewentualnym użyciem broni nuklearnej, w tym wobec państw NATO, włącznie z lotami patrolowymi bombowców strategicznych Tu-95 i Tu-160;

2) zaangażowanie wszystkich rodzajów wojsk oraz Okręgów Wojskowych (OW) i systemów uzbrojenia;

3) preferowanie dwóch rodzajów, a mianowicie corocznych ćwiczeń strategicznych, w jednym z czterech Okręgów Wojskowych, w trakcie których symulowane są warunki potencjalnego pola walki. Stanowią one swego rodzaju podsumowanie cyklu szkoleniowego sił zbrojnych w danym roku. Drugi zaś obejmuje ważne niezapowiedziane inspekcje, określane także jako nagłe ćwiczenia lub niezapowiedziane kontrole gotowości bojowej. Towarzyszy temu często podnoszenie stanu gotowości bojowej na poziomie Okręgu lub Okręgów Wojskowych;

4) udział regularnych formacji wojskowych podległych innym strukturom siłowym, tj. ministerstwom, służbom i agencjom, m.in.: wojsk wewnętrznych Ministerstwa Spraw Wewnętrznych (od 2016 r. Gwardia Narodowa), jednostek w ramach Federalnej Służby Bezpieczeństwa, w tym wojsk ochrony pogranicza;

14 J. Norberg, op. cit., p. 13-14, 30, 35-41; R.N. McDermott, Brothers Disunited: Russia's Use of Military Power in Ukraine, p. 8, http://fmso.leavenworth.army.mil/Collaboration/international/McDermott/ Brotherhood_McDermott_2015.pdf, inf. 08.09.2016.

15 J. Norberg, F. Westerlund, C. Vendil Pallin, R. Roffey, Russia's Armed Forces in 2016, [in:] Russian Military Capability in a Ten-Year Perspective - 2016, ed. G. Persson, Report no FOI-R--4326-SE, 2016, December, p. 52-56; J. Norberg, op. cit., p. 33-39; K. Giles, Assessing Russia's Reorganized..., p. 2; K.-H. Kamp, The Agenda of the NATO Summit in Warsaw, „Working Paper, Federal Academy for Security Policy" 2015, no. 9, p. 5, https://www.baks.bund.de/sites/baks010/files/working_paper_security_policy_9_2015.pdf, inf. 28.02.2018; M.P. Anderson, NATO Nuclear Deterrence: The Warsaw Summit and Beyond, „Connections: The Quarterly Journal” 2016, vol. 16, no. 4, p. 8. 
5) zaangażowanie cywilnych agencji, które uczestniczą w kwestiach dotyczących planowania obronnego państwa;

6) szeroki zakres przestrzenny, który obejmuje także terytorium państw członków Organizacji Układu o Bezpieczeństwie Zbiorowym (OUBZ), a w pewnych przypadkach Chiny i Serbię. Ponadto istotne znaczenie przywiązuje się do prowadzenia ćwiczeń na akwenach Morza Bałtyckiego i Morza Czarnego;

7) udział w części manewrów wojsk państw członków OUBZ oraz Chin, Mongolii i Serbii;

8) prowadzenie równolegle więcej niż jednego ćwiczenia o dużej skali lub też całego cyklu bezpośrednio po sobie realizowanych manewrów.

W Federacji przywiązuje się dużą wagę do corocznych manewrów strategicznych, które zasadniczo różnią się między sobą przyjętym do realizacji w ich trakcie celem głównym. Jako pierwsze wskazuje się manewry w roku 2009. W latach 2009-2018 przeprowadzono je w każdym z czterech OW, a mianowicie ${ }^{16}$ :

1) Zachodnim OW - Zachód-2009 (Zapad-2009 - udział brało około 12,5 tys. personelu) ${ }^{17}$, Zachód-2013 (90 tys. żołnierzy), Zachód-2017 (Zapad-2017, 14-20 września 2017 r.), w których uczestniczyło 12,7-100 tys. żołnierzy;

2) Wschodnim OW - Wschód-2010 (Wostok 2010 - 20 tys.), Wschód-2014 (19-25 września 2014 r., w których uczestniczyło 100-155 tys. żołnierzy; dodatkowo niezapowiedziane inspekcje objęły 3 ważne i 15 pomocniczych ćwiczeń), Wschód-2018 (11-17 września 2018 r.), w których uczestniczyło prawie 300 tys. żołnierzy;

3) Centralnym OW - Centrum-2011 (Centr-2011 - 12 tys.), Centrum-2015 (14-20 września 2015 r.), zaangażowano 95 tys. żółnierzy. Ponadto równoległe ćwiczenia przeprowadzono w Zachodnim OW i na Białorusi z udziałem 8 tys. żołnierzy, a także 2 ważne i 20 pomocniczych;

4) Południowym OW ${ }^{18}$ - Kaukaz-2012 (Kawkaz-2012 - 8 tys.), Kaukaz-2016 (5-10 września 2016 r. z udziałem 12,5-125 tys. żołnierzy oraz 4 ważne i 20 pomocniczych ćwiczeń).

16 J. Norberg, F. Westerlund, C. Vendil Pallin, R. Roffey, op. cit., p. 53; D. Johnson, op. cit.; J. Norberg, op. cit., p. 36, 57-74; The Military Balance 2015, London 2015, p. 482; V. Isachenkov, I. Sekretarek, Putin attends NATO-feared Zapad military exercise, https://www.defensenews.com/training-sim/2017/09/18/putin-attends-nato-feared-zapad-military-exercise/, inf. 04.01.2018; Minister obrony Niemiec zaniepokojona manewrami „Zapad 2017”, http://www.dw.com/pl/minister-obrony-niemiec-zaniepokojona-manewrami-zapad-2017/a-40525517, inf. 04.01.2018; Uczenija "Kawkaz" pokazała, kto w Czernom morie choziain, https://rg.ru/2016/09/22/reg-ufo/glavnye-fakty-o-strategicheskih-ucheniiah-kavkaz-2016. html, inf. 0303.2018; Strategic exercise Kavkaz-2016 begins in Russia's Southern Military District, http:// tass.com/defense/897869, inf. 03.03.2018; D. Johnson, op. cit.

17 W roku 2009 wskazywano, że w ramach ćwiczeń strategicznych Jesień-2009 (Osien'-2009) przeprowadzono trzy manewry na poziomie strategiczno-operacyjnym, tj.: Zachód-2009, Kaukaz-2009, Ładoga-2009 (Ladoga-2009) - łącznie około 29 tys. personelu. Zob. J. Norberg, op. cit., p. 36; W. Mochow, D. Ciemierow, Mnogolikaja «Osien'-2009», „Krasnaja Zwiezda” 30.08.2009, http://old. redstar.ru/2009/09/30_09/1_01.html, inf. 15.05.2019.

18 W roku 2008 - Północnokaukaski OW. 
Uwzględniając jednak badany problem, w tej części pracy analizie poddano manewry Kaukaz-2016 oraz Zachód-2017, ponieważ mają one najważniejsze znaczenie jako forma demonstracji siły militarnej Rosji wobec państw NATO. Natomiast Wschód-2014, Wschód-2018 i Centrum-2015 tylko zasygnalizowano.

Strategiczne manewry Wschód-2014 - największe od około 30 lat - poprzedzono ćwiczeniami w ramach niezapowiedzianych inspekcji, które miały na celu sprawdzenie gotowości bojowej jednostek Wschodniego OW w dniach 11-18 września. W ich ramach część oddziałów przetransportowano na odległość blisko 4 tys. km. Ponadto w ćwiczeniach Wschód-2014 wzięły udział również jednostki Zachodniego OW, przemieszczone ze swoich baz na Daleki Wschód na dystansie około 5-6 tys. km. Kwestie te wiązały się ze sprawdzeniem możliwości infrastruktury transportowej w tej części państwa, jak również rozmieszczenia wojsk $\mathrm{w}$ sytuacji walki z przeciwnikiem, przykładowo USA lub Japonią. W ich trakcie wykorzystano około 1,5 tys. czołgów, 5 tys. różnego rodzaju uzbrojenia i sprzętu wojskowego, 120 samolotów (w tym lotnictwa dalekiego zasięgu Tu-95MS i Tu-22M3) oraz 70 okrętów. Cel główny zakładał zapewnienie kompleksowej obrony Rosji na Dalekim Wschodzie. Podstawowe zadanie obejmowało obronę wybrzeża i wysp na półwyspach Kamczatka, Czukotka, południowej części Kraju Nadmorskiego oraz Wyspie Sachalin. Wiązały się one ze sprawdzeniem realnego stanu gotowości bojowej jednostek oraz systemu dowodzenia i kontroli nad takim ugrupowaniem wojska, w tym komponentu morskiego, działającego na tak rozległym obszarze. Po ich zakończeniu zwrócono uwagę na konieczność rozwoju infrastruktury w regionie, zwiększenia ilości sprzętu i niezbędnych zasobów, wzmocnienia systemu obrony powietrznej oraz szkolenia zmobilizowanych rezerwistów ${ }^{19}$.

Manewry Centrum-2015 poprzedzono niezapowiedzianym postawieniem w stan gotowości bojowej jednostek wojskowych w Centralnym OW. Przeprowadzono je na obszarze Centralnego OW oraz terytorium sojuszników Rosji w ramach OUBZ w Azji Centralnej. W ich trakcie wykorzystano około 7 tys. systemów uzbrojenia oraz sprzętu wojskowego, w tym m.in. 170 samolotów i 20 okrętów. Cel główny ćwiczeń zakładał udział w hipotetycznym międzynarodowym konflikcie zbrojnym w Azji Centralnej. Jednostki Armii Rosji miały za zadanie zwalczanie nielegalnych zbrojnych formacji terrorystycznych, tj. Państwa Islamskiego. W trakcie ćwiczeń sprawdzono także możliwość dyslokacji oddziałów wojskowych na dystansie do 5 tys. km, a także wykorzystanie różnych nowych systemów uzbrojenia i wyposażenia, w tym m.in. środków walki radioelektronicznej, wyrzutni rakiet Iskander oraz pocisków manewrujących o zakresie prawdopodobnie około $2000 \mathrm{~km}^{20}$.

19 Vostok 2014 strategic military exercises begin in Russia, http://tass.com/russia/750222, inf. 10.03.2018; Ekspierty: Uczenija «Wostok-2014» nielzia sopostawlat's sobytijami na Ukrainie, https://defendingrussia.ru/a/eksperty_uchenija_vostok_2014_nelzja_sopostavljat_s_sobytijami_na_ukraine-859/, inf. 10.03.2018; J. Norberg, op. cit., p. 64-66.

20 J. Norberg, op. cit., p. 66-69; A.M. Dyner, Rosyjskie manewry przygotowaniem do działań ekspedycyjnych, „Biuletyn PISM” 2015, nr 83, https://www.pism.pl/files/?id_plik=20534, inf. 10.12.2016. 
Manewry wojskowe Kaukaz-2016 poprzedzono ogłoszeniem przez ministra obrony Siergieja Szojgu w sierpniu 2016 r. kolejnej niezapowiedzianej kontroli gotowości bojowej Sił Zbrojnych Federacji w Południowym OW, części jednostek w Zachodnim OW, Centralnym OW, a także we Flocie Północnej. Aktywność ta objęła również głównodowodzących Sił Powietrzno-Kosmicznych i Wojsk Powietrzno-Desantowych. Kontrolę przeprowadzono w okresie 25-31 sierpnia $2016 \mathrm{r}$. i obejmowała ona postawienie wojsk w stan pełnej gotowości bojowej ${ }^{21}$. Strategiczne ćwiczenia wojskowe Kaukaz-2016 przeprowadzono w Południowym OW, a swoim zasięgiem objęły również Półwysep Krymski, akweny Morza Czarnego i Morza Kaspijskiego. Wzięły w nich udział także jednostki należące do Centralnego OW i Zachodniego OW. Jednorazowo uczestniczyło w nich nie więcej niż 12,5 tys. żołnierzy. Wykorzystano także ponad 100 samolotów i śmigłowców, 15 okrętów wojennych oraz inne rodzaje uzbrojenia. Brały w nich udział również jednostki Armii Rosji stacjonujące na Krymie. Podstawowe zadanie przyjęte do realizacji obejmowało sformowanie dużego zgrupowania wojsk, a następnie przemieszczenia na dużych dystansach, tj. około 65 tys. żołnierzy na odległość 3 tys. km w czasie 72 godzin. Cel główny ćwiczeń Kaukaz-2016 zakładał odparcie ataku ze strony „państwa zachodniego", przede wszystkim na Półwysep Krymski ${ }^{22}$.

Wyjątkowy rozmach aktywności militarnej oraz wykorzystanych sił i środków poprzedził manewry Zachód-2017 z udziałem wojsk Rosji i Białorusi. Po pierwsze, przed ich rozpoczęciem przeprowadzono mobilizację rezerwistów na dużą skalę w części regionów należących do Zachodniego OW. Dotyczyła ona przede wszystkim obwodu kaliningradzkiego i obwodu pskowskiego. Szacowano, iż masowy pobór miał prawdopodobnie objąć około 100 tys. rezerwistów, w tym także ojców rodzin wielodzietnych ${ }^{23}$. Po drugie, manewry te poprzedzono innymi formami aktywności obu państw, w tym do najważniejszych zaliczono ćwiczenia lub inne kursy szkoleniowe:

1) formacji walki radioelektronicznej - największe od powstania Federacji Rosyjskiej - z udziałem 1,5 tys. żołnierzy na terytorium Białorusi (19-25 maja 2017 r.);

2) formacji inżynieryjnych (13-15 czerwca);

3) formacji łączności (10-14 lipca);

4) jednostek obrony przeciwchemicznej (21-25 sierpnia);

${ }^{21}$ Rosja: niezapowiedziana kontrola gotowości bojowej wojsk, http://pl.sputniknews.com/ swiat/20160825/3764537/rosja-niezapowiedziana-kontrola-gotowosci-bojowej-wojsk.html, inf. 20.09.2016.

22 J. Norberg, op. cit., p. 69-71; A.M. Dyner, „Kaukaz 2016” kolejnym testem rosyjskich sił zbrojnych, „Biuletyn PISM” 2016, nr 63, https://www.pism.pl/publikacje/biuletyn/nr-63-1413\#, inf. 10.12.2016; Rosja szykuje się do ćwiczeń. Ukraina podwyższa poziom zagrożenia, http://www.tvn24.pl/wiadomosci-ze-swiata,2/ukraina-podwyzszony-poziom-zagrozenia,666847.html, inf. 10.12.2016; M. Fryc, From Wales to Warsaw and Beyond: NATO's Strategic Adaptation to the Russian Resurgence on Europe's Eastern Flank, „Connections: The Quarterly Journal” 2016, vol. 15, no. 4, p. 55.

${ }_{23}$ M. Dura, Masowy pobór rezerwistów w zachodniej Rosji. Wstęp do „Zapad-2017”?, http://www. defence24.pl/653086, masowy-pobor-rezerwistow-w-zachodniej-rosji-wstep-do-zapad-2017, inf. 08.01.2018. 
5) jednostek obrony przeciwlotniczej, połączone z rozmieszczeniem samolotów z Rosji w bazach na Białorusi (21-25 sierpnia);

6) formacji logistycznych, obejmujących zaopatrzenie rurociągami walczących wojsk w paliwo (21-25 sierpnia);

7) w ramach dużych ćwiczeń obrony powietrznej w Zachodnim OW, z udziałem 5 tys. żołnierzy (lipiec);

8) sprawdzanie poziomu gotowości bojowej jednostek oraz systemów dowodzenia w Zachodnim OW, w tym m.in. 1 Armii Pancernej (sierpień) ${ }^{24}$.

Właściwe manewry Zachód-2017 przeprowadzono w dniach 14-20 września 2017 r. na terytorium Białorusi i w zachodniej części Rosji. Według oficjalnych zapewnień uczestniczyło w nich około 12,7 tys. żołnierzy z Rosji i Białorusi. Cel główny strategicznych manewrów zakładał odparcie ataku ze strony trzech fikcyjnych państw-agresorów, tj. Wiesznorii, Łubienii i Wiesrabii. Jeden z etapów ćwiczeń był prowadzony przez wojska pancerne około $100 \mathrm{~km}$ od granicy z Estonią. Ponadto brały w nich udział także bombowce strategiczne, które odbyły loty również nad Morzem Bałtyckim, oraz wyrzutnie pocisków balistycznych Iskander-M. Według dowódcy Narodowych Sił Zbrojnych Estonii generała Riho Terrasa, w ramach manewrów wojskowych Zachód-2017 Armia Rosji ćwiczyła na dużą skalę wojnę konwencjonalną z Sojuszem Północnoatlantyckim w Europie. Pojawiły się także opinie, że jednym z celów tych ćwiczeń było zastraszenie. Ponadto w tym czasie prowadzono także inne równoległe manewry wojskowe ${ }^{25}$.

Manewry Wschód-2018 poprzedzono trwającymi od lipca do początku września 2018 r. działaniami logistycznymi, które miały na celu dyslokację zarówno personelu, jak i techniki wojskowej do miejsc koncentracji i przyszłych ćwiczeń. Do najważniejszych form aktywności, które poprzedziły te ćwiczenia lub były równoległe z nimi prowadzone, należy zaliczyć26:

1) 16 specjalistycznych ćwiczeń jednostek pomocniczych;

2) ćwiczenia Floty Północnej Federacji (połowa sierpnia);

3) ćwiczenia jednostek Centralnego OW i Wschodniego OW;

24 A. Wilk, Ćwiczenia Zapad-2017 - wojna (na razie) informacyjna, „Komentarze OSW” 2017, nr 249, https://www.osw.waw.pl/pl/publikacje/komentarze-osw/2017-09-04/cwiczenia-zapad-2017-wojna-na-razie-informacyjna, inf. 04.01.2018.

25 V. Isachenkov, I. Sekretarek, Putin attends NATO-feared...; J. Norberg, op. cit., p. 71-74; A. Wilk, Ćwiczenia Zapad-2017...; Minister obrony Niemiec...; Manewry Zapad'2017, https://www.tvn24.pl/ raporty/manewry-zapad-17,1208, inf. 04.01.2018; J. Röpcke, Estonian Defence Forces Commander: Russia simulated a large-scale military attack against NATO, http://www.bild.de/politik/ausland/ bild-international/zapad-english-54375924.bild.html, inf. 08.01.2018; „Ujawniono pewne braki”. Nowe zalecenia Putina po strategicznych manewrach, https://www.tvn24.pl/wiadomosci-ze-swiata,2/ putin-polecil-podwyzszanie-gotowosci-mobilizacyjnej-po-zapad-17,792381.html, inf. 04.01.2018; Zapad 2017: Wypadek bombowca Tu-22M, http://www.defence24.pl/zapad-2017-wypadek-bombowca-tu-22m, inf. 14.01.2018; A.D. Gronoskij, Rossijsko-biełorusskije wojennyje uczenija - rieakcyja, [w: NATO, Zapad-Wostok-Rossija 2017. Jeżegodnik, D. B. Małyszewa, W. G. Choros, Moskwa 2018, s. 89-91.

26 D. Johnson, op. cit. 
4) ćwiczenia, które objęły mobilizację rezerwistów;

5) ćwiczenia, które objęły mobilizację przemysłu.

Właściwe manewry Wschód-2018 przeprowadzono na obszarze Wschodniego OW, a także na akwenach Morza Beringa, Morza Japońskiego i Morza Ochockiego. Według oficjalnych informacji uczestniczyło w nich prawie 300 tys. personelu, w tym prawdopodobnie 75-100 tys. jednostek bojowych ze Wschodniego OW i Centralnego OW oraz Floty Północnej i Floty Pacyfiku. Według Ministerstwa Obrony Federacji, wykorzystanych miało zostać 36 tys. uzbrojenia i wyposażenia oraz 1 tys. samolotów i śmigłowców. Ponadto brały w nich udział siły zbrojne Chin (3 tys. personelu) i Mongolii. Wykorzystano $\mathrm{w}$ ich trakcie także bombowce strategiczne oraz pociski balistyczne typu Iskander i manewrujące Moskit. Manewry uznano za największe od rozpadu ZSRR. Cel manewrów zakładał obronę wybrzeża ${ }^{27}$.

Od roku 2013 r. Rosja przeprowadziła bardzo dużą liczbę manewrów i niezapowiedzianych inspekcji, które objęły zarówno siły strategiczne, jak i konwencjonalne. Pod względem zaangażowanych sił i środków obejmowały one znaczący potencjał, nawet na poziomie do 150-160 tys. żołnierzy, jak też około 5-7 tys. systemów uzbrojenia wojsk lądowych, ale także samoloty bojowe, śmigłowce oraz niekiedy okręty wojenne. Zakres ćwiczeń zakładał m.in. przegrupowanie na pozycje bojowe oraz transport koleją związków pancernych i zmotoryzowanych na długich dystansach, tj. około 1 tys. km lub dłuższych. Na większą skalę uczestniczą w nich również okręty wojenne szczególnie Floty Bałtyckiej i Floty Czarnomorskiej, a także Floty Północnej. Ponadto w trakcie tych niezapowiedzianych manewrów i nagłego ogłaszania gotowości bojowej wojsk symuluje się (od roku 2000 r.) możliwość użycia broni jądrowej, najczęściej przenoszonej przez samoloty bombowe. I tak, w marcu 2015 r. w obwodzie kaliningradzkim rozmieszczono wyrzutnie Iskander-M, na Krymie bombowce Tu-22M3. Natomiast maszyny Tu-22M3, Tu-160 i Tu-95MS wykonywały loty w Arktyce. Niezapowiedziane inspekcje objęly także komponent lądowy i morski triady nuklearnej Federacji. W ramach tych ćwiczeń zakładano również możliwość prowadzenia walki na dystansie, w tym skoordynowane działanie wyrzutni pocisków balistycznych Iskander-M i bombowców strategicznych. Istotną kwestię stanowi testowanie w ramach zarówno manewrów strategicznych, jak i innych ćwiczeń wojskowych różnych systemów uzbrojenia, $\mathrm{w}$ tym najnowszych generacji ${ }^{28}$.

27 Ibidem.

28 J. Norberg, F. Westerlund, C. Vendil Pallin, R. Roffey, op. cit., p. 52-54; J. Norberg, op. cit., p. 42-43; The Military Balance 2017, London 2017, p. 35, 551; P. Felgenhauer, Yanukovych Recognized as Legitimate President in Exile in Russia, „Eurasia Daily Monitor” 2014, vol. 11, 27, no. 38, http://www. jamestown.org/single/?tx_ttnews\%5Btt_news\%5D=42022\&amp;no_cache=1\#.V9bRMjW-d0S, inf. 12.09.2016; J. Biersack, S. O'Lear, The geopolitics of Russia's annexation of Crimea: narratives, identity, silences, and energy, „Eurasian Geography and Economics” 2015, vol. 55, no. 3, p. 255-256; R.N. McDermott, Brothers Disunited: Russia's..., p. 12; The Military Balance 2015..., p. 482; Russia Targets NATO With Military Exercises, https://www.stratfor.com/analysis/russia-targets-nato-military-exercises, inf. 01.12.2016; Stratfor: Ostatnie manewry wojskowe Rosji to alarm dla Europy, 
Należy zaznaczyć, iż ćwiczenia prowadziły także inne struktury siłowe w Rosji, które sprawdzały swoją gotowość w przypadku pojawienia się protestów społecznych. Działania objęły uszczelnienie granic, zapewnienie przestrzegania prawa i utrzymania porządku wewnętrznego, obronę terytorium, zwalczanie terroryzmu i ochronę obiektów strategicznych ${ }^{29}$.

Siły Zbrojne Rosji prowadziły także wspólne manewry wojskowe z państwami OUBZ, w tym m.in. pod kryptonimami Niezłomne braterstwo, Współdziałanie, Tarcza Związku. Ich zakres obejmował także przećwiczenie wspólnych operacji pokojowych prowadzonych przez „kolektywne siły pokojowe”, w założeniu mających działać w regionie kryzysu, tj. w warunkach zbliżonych do sytuacji na Ukrainie. Należy także wskazać na manewry Misje pokojowe, w których ćwiczono operacje antyterrorystycz$\mathrm{ne}^{30}$. Ponadto Rosja wspólnie z Białorusią i Serbią prowadziła coroczne ćwiczenia Słowiańskie braterstwo. Natomiast Federacja wraz z Chinami realizowała także manewry Wspótpraca oraz Morska Wspótpraca ${ }^{31}$.

Należy także wskazać na spektakularne przypadki wykorzystania manewrów wojskowych jako formy demonstracji siły militarnej przez Federację. Przykładowo około 2 tys. żołnierzy Wojsk Powietrzno-Desantowych prowadziło ćwiczenia tuż przy granicy z Estonią. W tym samym dniu, tj. 25 lutego 2015 r., jednostki Armii USA uczestniczyły w paradzie wojskowej z okazji Dnia Niepodległości Estonii w mieście nadgranicznym Narwa ${ }^{32}$.

Według oficjalnych deklaracji władz Rosji, wszystkie strategiczne manewry wojskowe miały charakter typowo obronny. Ponadto ta forma aktywności militarnej zakładała także pokazanie wiarygodności Federacji, zgodnie z zasadą, iż siły zbrojne mogą zostać użyte $\mathrm{w}$ działaniach zbrojnych na poziomie strategicznym na wszystkich kierunkach. Stanowi to „ważny” przekaz dla państw sąsiadujących. Jednocześnie coroczne

http://forsal.pl/artykuly/861173,stratfor-ostatnie-manewry-wojskowe-rosji-to-alarm-dla-europy. html?gclid=CI7V65SMutACFcn7cgodiJwEWA, inf. 03.12.2016; K. Giles, New Troop Deployments Signal NATO Commitment to Baltics, The Royal Institute of International Affairs, 2016, 2 November, https://www.chathamhouse.org/expert/comment/new-troop-deployments-signal-nato-commitment-baltics, inf. 28.02.2018; M. Fryc, From Wales to Warsaw..., p. 47, 60; J. Lough, NATO Summit Shows Moscow a Reinvigorated Alliance, https://www.chathamhouse.org/expert/comment/ nato-summit-shows-moscow-reinvigorated-alliance, inf. 28.02.2018.

29 A. Monaghan, Russian State Mobilization..., p. 25-26.

30 R.N. McDermott, Brothers Disunited: Russia's..., p. 21-22; The Military Balance 2015..., p. 481; The Military Balance 2016, London 2016, p. 482; A.M. Dyner, Rosyjskie manewry przygotowaniem...; Pokaz sity państw anty-NATO. Trzy razy więcej żołnierzy na manewrach, http://www.tvn24.pl/wiadomosci-ze-swiata,2/cwiczenia-odkb-w-rosji,667144.html, inf. 10.12.2016; J. Norberg, F. Westerlund, C. Vendil Pallin, R. Roffey, op. cit., p. 52-54; The Military Balance 2015... p. 482; The Military Balance $2017 \ldots$, p. 551.

31 The Military Balance 2017..., p. 551; A. M. Dyner, Rosyjskie manewry przygotowaniem...

32 P. McLeary, US, Russian Troops Show off Hardware Just Miles Apart, https://www.defensenews. com/opinion/intercepts/2015/02/26/us-russian-troops-show-off-hardware-just-miles-apart/, inf. 14.01.2018. 
ćwiczenia strategiczne wskazywały, w jaki sposób Federacja może wykorzystać instrumenty militarne w wojnach o charakterze regionalnym, np. w celu zwiększenia swoich wpływów w świecie wielobiegunowym lub urzeczywistniania swoich interesów ${ }^{33}$.

Rosja do realizowanych manewrów wojskowych zaczęła angażować coraz większe siły, w których sprawdzano także koordynację działań z innymi służbami. W ramach tzw. ćwiczeń strategicznych zakładano szybkie przemieszczanie jednostek wojskowych na dystansach kilku tysięcy kilometrów ${ }^{34}$.

Siły Zbrojne Federacji Rosyjskiej przeprowadzają w ciągu roku kilka tysięcy ćwiczeń wojskowych, zróżnicowanych pod względem skali oraz charakteru, włączając w to również niezapowiedziane sprawdzenie gotowości bojowej wojsk. I tak, różne formy aktywności militarnej w latach 2015 i 2016 szacowano odpowiednio na poziomie około 5 tys. i 4 tys. ${ }^{35}$.

Niezapowiedziane inspekcje po pierwsze mają na celu sprawdzenie, tj. ocenę stanu, a w konsekwencji poprawę gotowości bojowej wszystkich okręgów wojskowych, ale także różnych służb i oddziałów. Po drugie, realizacja nagłych inspekcji gotowości bojowej ma przyczynić się do szybkiego przejścia wojsk ze stanu pokoju do stanu wojny. Po trzecie, mogą one stanowić pewnego rodzaju „zabezpieczenie” czy też „usprawiedliwienie" w przypadku dyslokacji części jednostek wojsk powietrznodesantowych oraz formacji specjalnych (Specnaz). Ponadto, realizowane formy aktywności militarnej dają możliwość przygotowania do prowadzenia przez Rosję wojny hybrydowej ${ }^{36}$.

W konsekwencji Siły Zbrojne Rosji oraz wspierające je struktury siłowe są przygotowywane do wczesnego reagowania w przypadku pojawienia się sytuacji kryzysowej, konfliktu lub wojny, aby powstrzymać działania przeciwnika i nie dać mu się zaskoczyć. Przyjęte i realizowane programy szkoleniowe kładą duży nacisk na podejmowanie szybkich działań. Obejmują one również nagłe inspekcje gotowości bojowej lub niezapowiedziane i przyśpieszone ćwiczenia zarówno wojsk konwencjonalnych, jak i sił jądrowych. Prowadzone przez Federację od roku 2009 duże manewry wojskowe, a także ich założenia i przebieg stanowią wyzwanie dla państw sąsiadujących, które wydają się być ich celem ${ }^{37}$. Jednocześnie $\mathrm{w}$ znacznym stopniu przekładają się na poziom bezpieczeństwa NATO, a szczególnie państw jego wschodniej flanki.

33 J. Norberg, op. cit., p. 49-50.

34 A. Monaghan, Russian State Mobilization Moving the Country on to a War Footing, "Research Paper" 2016, May, p. 25-26, https://www.chathamhouse.org/sites/files/chathamhouse/publications/ research/2016-05-20-russian-state-mobilization-monaghan-2.pdf, inf. 02.03.2018.

35 J. Norberg, op. cit., p. 30; A.M. Dyner, „Kaukaz 2016” kolejnym testem ...; O. Ognokolenko, Ukraina stanowitsia dla Rossii stratiegiczeskim protiwnikom, http://www.ng.ru/armies/2016-07-29/1_ukraina. html, inf. 25.11.2016.

36 M. Fryc, From Wales to Warsaw..., p. 55; J. Norberg, op. cit., p. 30, 49-50; R.N. McDermott, Brothers Disunited: Russia's..., p. 19; S. Koziej, Strategiczne wnioski z manewrów...

37 K. Giles, Russia's 'New' Tools..., p. 9, 19. 
Manewry wojskowe są jedną z najważniejszych form demonstracji siły militarnej, jako instrumentu militarnego w polityce zagranicznej Federacji Rosyjskiej. Szczególne miejsce zajmują coroczne strategiczne ćwiczenia wojskowe, które odbywają się we wrześniu w jednym z czterech Okręgów Wojskowych. Stanowią one podsumowanie cyklu aktywności wojskowej w danym roku. Przyjęte we wstępie niniejszego artykułu hipotezy badawcze się potwierdziły. Po pierwsze, strategiczne manewry wojskowe mimo oficjalnych deklaracji najważniejszych decydentów, iż mają założenie obronne, w praktyce ze względu na ich charakter i zakres są postrzegane przez państwa Europy Środkowo-Wschodniej jako ofensywne. Po drugie, manewry wojskowe połączone z niezapowiedzianymi i nagłymi inspekcjami, którym towarzyszy także przegrupowanie jednostek, znacząco podniosły możliwości bojowe Sił Zbrojnych Federacji Rosyjskiej.

Manewry wojskowe prowadzone przez Siły Zbrojne Rosji oraz inne struktury siłowe mają znaczenie zarówno w wymiarze politycznym, jak i militarnym. Uwzględniając zakres, charakter i intensywność prowadzonych ćwiczeń wojskowych oraz innych powiązanych z nimi form aktywności, w tym nagłych i niezapowiedzianych inspekcji, wywołują one zaniepokojenie państw sąsiadów Federacji, szczególnie w Europie Środkowo-Wschodniej. W sposób negatywny wpływają na erozję systemu bezpieczeństwa w Europie.

W porównaniu do wojny z Gruzją w roku 2008 nastąpił znaczący wzrost możliwości bojowych Sił Zbrojnych Rosji, a także sprawności dowodzenia i koordynacji działań dużych mieszanych ugrupowań wojsk. Należy podkreślić, iż celem manewrów wojskowych, w tym strategicznych oraz niezapowiedzianych inspekcji prowadzonych w Federacji Rosyjskiej jest podniesienie stanu gotowości bojowej wojsk, możliwości szybszej reakcji na pojawienie się ewentualnych zagrożeń militarnych, zmniejszenie uzależnienia od warunków terenowych, pory roku, eliminowanie niedociągnięć w wyszkoleniu wojsk. Kwestie te przyczyniły się do zwiększenia możliwości podejmowania i realizacji operacji o charakterze strategicznym. W konsekwencji Siły Zbrojne Rosji zostały przygotowane do prowadzenia działań zgodnie z wolą decydentów, także na poziomie strategicznym w zróżnicowanych warunkach, które występują na obszarze Wspólnoty Niepodległych Państw oraz graniczących z nią regionach międzynarodowych.

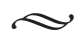

Streszczenie: Zwycięstwo Federacji Rosyjskiej w wojnie ze stosunkowo słabą pod względem posiadanego potencjału militarnego Gruzją w sierpniu 2008 r. wręcz obnażyło wiele wad armii. Sytuacja ta wymusiła podjęcie w 2009 r. reformy sił zbrojnych. Jednym z jej założeń było podniesienie możliwości bojowych armii przez prowadzenie niemal "permanentnego" szkolenia żołnierzy w warunkach odzwierciedlających potencjalne warunki działań zbrojnych. Uwzględniając skalę i charakter prowadzonych manewrów wojskowych, w tym corocznych strategicznych ćwiczeń, jak również innych form aktywności, szczególnie niezapowiedzianych inspekcji, znacząco wykraczały one poza płaszczyznę wojskową. Wzrost zdolności oraz inicjatywy Federacji do podejmowania szerszych działań wojskowych bez 
wyraźnego ostrzeżenia stanowi zagrożenie dla utrzymania bezpieczeństwa i stabilności na Obszarze Transatlantyckim. Zostały one „zaprezentowane” podczas aneksji Krymu w Donbasie, a później w operacji w Syrii. W konsekwencji relacje Rosji z Zachodem uległy stopniowo znacznemu pogorszeniu, aż do poziomu określanego jako "nowa zimna wojna".

W porównaniu do wojny z Gruzją w roku 2008 nastąpił znaczący wzrost możliwości bojowych Armii Federacji Rosyjskiej, a także sprawności dowodzenia i koordynacji działań dużych mieszanych ugrupowań wojsk. Siły zbrojne oraz inne struktury siłowe Rosji są przygotowane do szybkiego przejścia ze stanu pokoju do stanu wojny, w przypadku pojawienia się zagrożenia lub też podjęcia decyzji przez ośrodek władzy. Ponadto szybkość i sprawność prowadzenia operacji militarnych, w tym na poziomie strategicznym, znacząco może niwelować przewagę potencjału militarnego w wymiarze sił konwencjonalnych Organizacji Traktatu Północnoatlantyckiego.

Słowa kluczowe: Federacja Rosyjska, Siły Zbrojne Federacji Rosyjskiej, manewry wojskowe, strategiczne manewry wojskowe, demonstracja siły militarnej, Obszar Transatlantycki, Europa.

\section{Военные маневры как форма демонстрации военной мощи Российской Федерации в Европе}

Аннотация: Победа Российской Федерации в войне с относительно слабой с точки зрения военного потенциала Грузией в августе 2008 года, вскрыла многие недостатки армии. Эта ситуация вынудила реформу вооруженных сил в 2009 году. Одним из ее предположений было увеличение боевых возможностей армии путем проведения почти «постоянной» подготовки солдат в условиях, отражающих различные потенциальные театры военных действий. Учитывая масштабы и характер военных маневров, проводимых в ежегодных стратегических учениях, а также другие виды деятельности, особенно внезапные проверки, они значительно превысили пределы военных. Увеличение способности и инициативы Федерации проводить более широкие военные операции без четкого предупреждения создает угрозу поддержанию безопасности и стабильности в трансатлантическом регионе. Они были «представлены» во время аннексии Крыма, на Донбассе, а затем и в ходе операции в Сирии. Как следствие, отношения России с Западом постепенно значительно ухудшились, до уровня, известного как «новая холодная война». По сравнению с войной с Грузией в 2008 году, произошло значительное увеличение боевых возможностей Армии Российской Федерации, а также эффективности командования и координации действий крупных смешанных групп армий. Вооруженные силы и другие силовые структуры России готовы к быстрому переходу из состояния мира в состояние войны в случае угрозы. Кроме того, скорость и эффективность военных операций, в том числе на стратегическом уровне, могут значительно уменьшить преимущество военного потенциала в измерении обычных сил Организации Североатлантического договора.

Ключевые слова: Российская Федерация, Вооруженные силы Российской Федерации, военные маневры, стратегические военные маневры, демонстрация военной силы, Трансатлантический район, Европа. 
Pobrane z czasopisma Wschód Europy http://journals.umcs.pl/we

Data: 26/04/2023 13:35:38

Manewry wojskowe jako forma demonstracji sity militarnej Federacji Rosyjskiej w Europie

\section{Military maneuvers as a form of demonstration of the military strength of the Russian Federation in Europe}

Abstract: The victory of the Russian Federation in the war with relatively weak, as far as military potential is concerned, Georgia in August 2008 exposed many flaws of the army. This situation made the authorities undertake the reform of the armed forces in 2009. One of its assumptions was raising the combat readiness through nearly "permanent" military training of soldiers in conditions which reflect various potential theatres of military operations. Considering the scale and character of conducted military maneuvers, including annual strategic trainings as well as other forms of activity such as unexpected inspections, they vastly go beyond military sphere. The increase of military ability and the initiatives of the Federation to undertake many military operations without clear warning, constitute the threat for security and stability in the Transatlantic Area. They were "presented" during the annexation of Crimea, in Donbas, and later during the military operations in Syria. As a consequence, the relations of Russia with the West gradually underwent a significant deterioration till they reach the level called" a new cold war". In comparison to the war with Georgia in 2008 there was a significant growth of combat abilities of the Army of the Russian Federation and also the increase of the efficiency of commanding and coordination of operations of large composite military orders. Armed forces and other power structures of Russia are prepared to a quick transition from the state of peace to the state of war, in case of the threat or the decision of the authority. Moreover, the speed and efficiency of conducting military operations at this strategic level may significantly eliminate the advantage of the military capacity in the dimension of conventional forces of the North Atlantic Treaty Organization.

Keywords: Russian Federation, Armed Forces of the Russian Federation, military operation, strategic military maneuvers, demonstration of military power, Transatlantic Area, Europe.

\section{Bibliografia}

\section{Dokumenty i materiały}

Russia Military Power 2017: Building a Military to Support Great Power Aspirations, Defense Intelligence Agency Report, https://publicintelligence.net/dia-russia-military-power-2017/.

\section{Artykuły. Monografie. Opracowania}

Anderson M.P., NATO Nuclear Deterrence: The Warsaw Summit and Beyond, "Connections: The Quarterly Journal" 2016, vol. 16, no. 4. DOl: https://doi.org/10.11610/Connections.15.4.01.

Biersack J., O'Lear S., The geopolitics of Russia's annexation of Crimea: narratives, identity, silences, and energy , Eurasian Geography and Economics" 2015, vol. 55, no. 3.

Braun T., The Russian Military in 2020: Russia's Way Back to Power Projection? Implications for NATO, „Connections: The Quarterly Journal” 2012, vol. 11, no. 2. DOl: https://doi.org/10.11610/Connections.11.2.05.

Ciolan I.M., The Role of The "New Cold War" Concept In Constructing Russia'S Great Power Narrative, „CES Working Papers, Centre for European Studies, Alexandru Ioan Cuza University” 2016, vol. 8, issue 4. 
Competing Western and Russian narratives on the European order: Is there common ground?, Conference Report, eds T. Frear, L. Kulesa, 2016, April, https://www.europeanleadershipnetwork.org/wp-content/uploads/2017/10/ELN-Competing-Narratives-Report.pdf.

Felgenhauer P., Yanukovych Recognized as Legitimate President in Exile in Russia, „Eurasia Daily Monitor" 27.02.2014, vol. 11, no. 38.

Fryc M., From Wales to Warsaw and Beyond: NATO's Strategic Adaptation to the Russian Resurgence on Europe's Eastern Flank, „Connections: The Quarterly Journal” 2016, vol. 15, no. 4. DOl: https://doi. org/10.11610/Connections.15.4.03.

Galeotti M., 'Hybrid War' and 'Little Green Men': How It Works, and How It Doesn't, [in:] Ukraine and Russia. People, Politics, Propaganda and Perspectives, eds A. Pikulicka-Wilczewska, R. Sakwa, Bristol 2016.

Giles K., Russia's 'New' Tools for Confronting the West Continuity and Innovation in Moscow's Exercise of Power, „Research Paper” 2016, https://www.chathamhouse.org/sites/files/chathamhouse/publications/2016-03-russia-new-tools-giles.pdf.

Gronoskij A. D., Rossijsko-biełorusskije wojennyje uczenija - rieakcyja, [w:] NATO, Zapad-Wostok-Rossija 2017. Jeżegodnik, D. B. Małyszewa, W. G. Choros, Moskwa 2018.

Kamp K.-H., The Agenda of the NATO Summit in Warsaw, "Working Paper, Federal Academy for Security Policy" 2015, no. 9.

Koziej S., Strategiczne wnioski z manewrów Zapad 2017: budowa przez Rosję „bezpiecznika” w neozimnowojennej grze z Zachodem, http://koziej.pl/wp-content/uploads/2017/09/Wnioski-z-ZAPAD-Pulaski_Policy_Papers_Nr_19_17.pdf.

Le Mière Ch., Maritime Diplomacy in the 21st Century. Drivers and Challenges, London-New York 2014. Łoś R., Teoria stosunków międzynarodowych. Wybrane zagadnienia, Łódź 2001.

Matsaberidze D., Russia vs. EU/US through Georgia and Ukraine, "Connections: The Quarterly Journal" 2015, vol. 14, no. 2. Dol: https://doi.org/10.11610/Connections.14.2.06.

McDermott R.N., Brothers Disunited: Russia's Use of Military Power in Ukraine, http://fmso.leavenworth. army.mil/Collaboration/international/McDermott/Brotherhood_McDermott_2015.pdf.

Monaghan A., A 'New Cold War'? Abusing History, Misunderstanding Russia, „Research Paper” 2015, https://www.chathamhouse.org/sites/files/chathamhouse/field/ field_document/20150522ColdWarRussiaMonaghan.pdf.

Monaghan A., Russian State Mobilization Moving the Country on to a War Footing, "Research Paper" 2016, https://www.chathamhouse.org/sites/files/chathamhouse/publications/research/2016-05-20-russian-state-mobilization-monaghan-2.pdf.

Morgenthau H. J., przejrzał i uzupełnił K. W. Thompson, Polityka między narodami. Walka o potęgę i pokój. Wydanie skrócone, Warszawa 2010.

Nation R. C., Russia and the Caucasus, „Connections: The Quarterly Journal” 2015, vol. 14, no. 2. DOI: https://doi.org/10.11610/Connections.14.2.01.

NATO, Zapad-Wostok-Rossija 2017. Jeżegodnik, red. D.B. Małyszewa, W.G. Choros, Moskwa 2018.

Norberg J., Training for War - What Military Exercises 2009-2017. Say About the Fighting Power of Russia's Armed Forces, Report no FOI-R--4627-SE, 2018, October.

Norberg J., Westerlund F., Vendil Pallin C., Roffey R., Russia's Armed Forces in 2016, [in:] Russian Milltary Capability in a Ten-Year Perspective - 2016, ed. G. Persson, Report no FOI-R--4326-SE, 2016, December. 
Pobrane z czasopisma Wschód Europy http://journals.umcs.pl/we

Data: 26/04/2023 13:35:38

Manewry wojskowe jako forma demonstracji sity militarnej Federacji Rosyjskiej w Europie

Rumer E., Russia and the Security of Europe, Washington 2016, http://carnegieendowment.org/files/ CP_276_Rumer_Russia_Final.pdf.

Russian Military Capability in a Ten-Year Perspective - 2016, ed. G. Persson, Report no FOI-R--4326-SE, 2016, December.

Studzińska Z., How Russia, Step by Step, Wants to Regain an Imperial Role in the Global and European Security System, „Connections: The Quarterly Journal” 2014, vol. 14, no. 4. DOl: https://doi. org/10.11610/Connections.14.4.03

The Military Balance 2015, London 2015.

The Military Balance 2016, London 2016.

The Military Balance 2017, London 2017.

Tier D., Regional Alliances: A Political, Military, and Economic Strategy to Confront Hostile Regional Powers, „Connections: The Quarterly Journal” 2014, vol. 13, no. 4. DOl: https://doi.org/10.11610/Connections.13.4.02.

Topolski I., Instrument militarny polityki zagranicznej państwa, „TEKA Komisji Politologii i Stosunków Międzynarodowych" 2016, t. 11, z. 3.

Ukraine and Russia. People, Politics, Propaganda and Perspectives, eds A. Pikulicka-Wilczewska, R. Sakwa, Bristol 2016.

\section{Źródła internetowe}

BILD.de, https://www.bild.de/

Carnegie Endowment for International Peace, http://carnegieendowment.org/

Chatham House. The Royal Institute of International Affairs, https://www.chathamhouse.org

„Defence24. Bezpieczeństwo. Wojsko. Przemyst", http://www.defence24.pl/

"DefenseNews", http://www. defensenews.com

„Deutsche Welle", http://www.dw.com/pl/start/s-11394

Forsal.pl, Forsal.pl

„Krasnaja Zwiezda", http://old.redstar.ru

"Mauldin Economics", http://www.mauldineconomics.com/

"Niezawisimaja", http://www.ng.ru

Ośrodek Studiów Wschodnich, https://www.osw.waw.pl

„Przegląd NATO", https://www.nato.int/docu/review

Polski Instytut Spraw Międzynarodowych, https://www.pism.pl

„Rossijskaja Gazieta", https://rg.ru/

„Sputnik Polska", http://pl.sputniknews.com

Stratfor, https://www.stratfor.com

TASS Russian News Agency, tass.com

TVN24, http://www.tvn24.pl

„Zaszcziszczat' Rossiju”, https://defendingrussia.ru/ 